\title{
Agro-morphological characterization of horned melon (Cucumis metuliferus) accessions from selected agro-ecological zones in Kenya
}

\author{
Marline Hanny Owino*, Bernard Mukiri Gichimu and Phyllis Wambui Muturi
}

Department of Agricultural Resource Management, University of Embu, P.O. Box 6 - 60100, Embu, Kenya

\author{
*Corresponding author: hannymarline@gmail.com
}

\begin{abstract}
Morphological characterization of genotypes is fundamental in providing information on their genetic status to guide on their conservation and improvement. The objective of this study was to determine agro-morphological diversity within horned melon in Kenya. The study was carried out in two seasons at the University of Embu in Kenya. The study characterized 19 horned melon accessions collected from different agro-ecological zones in Eastern, Central and Western regions in Kenya. The experiment was laid out in a randomized complete block design with three replications. Morphological characterization of the accessions was based on melon descriptors from International Plant Genetic Resources Institute (IPGRI) with slight modifications. Significant differences were observed in all the quantitative traits except the number of branches and main vine length. However, qualitative variations were only observed in fruit shape, rind colour and seed shape. Principle Component Analysis (PCA) showed that fruit weight, main vine length and days to maturity had the highest contribution to the observed diversity. Cluster analysis separated the accessions into seven groups with between classes diversity of $79.20 \%$ and within classes diversity of $20.80 \%$. The diversity observed can be exploited by plant breeders for genetic improvement of the crop.
\end{abstract}

Keywords: Genetic Diversity, Agronomic Variation, Qualitative and Quantitative Characters.

Abbreviations: ANOVA_analysis of variance; AEZ_agro-ecological zone; FAO_Food and Agriculture Organization; GPS_Global Positioning System; HCD_Horticultural Crops Directorate; IPGRI_International Plant Genetic Resources Institute; LH_lower highland; LM_lower midland; NS_Not Significant; PCA_principal component analysis; SE_standard error; SNK_Students Newman's Keuls; TSP_triple super phosphate; UH_upper highland; UM_upper midland; UPGMA_unweighted pair group method with arithmetic average.

\section{Introduction}

Cucurbits are widely cultivated around the world and are among the most important fruits consumed in Africa since they are rich in several vitamins and minerals (Deguine et al., 2015). They are mainly annual vines belonging to the family Cucurbitaceae. This family comprises of about 118 genera and 825 species with their members spread mainly in regions of tropical and subtropical worldwide (Wang et al., 2007). They are ranked among the major vegetable fruits grown in Kenya and exported abroad for their nutritional value and economic significance as foreign exchange earners (Tshilidzi et al., 2016). The major species of cucurbits grown in Kenya are butternut (Cucurbita moschata), pumpkin (Cucurbita maxima), cucumber (Cucumis sativus), courgettes (Cucurbita pepo), and watermelon (Citrullus lanatus) (HCD, 2016). Minor species include horned melon (Cucumis metuliferus) or kiwano, which has high economic and nutritional value that is yet to be fully exploited (Aliero and Gumi, 2012).

Horned melon (C. metuliferus) belongs to the genus Cucumis and species metuliferus. It has many common names like jelly melon (English), Kiwano, Melano (Israel), bitter wild cucumber (South Africa), thorn melon and many others. Its fruit has horn-like spines, hence the name "horned melon" (Wannang, 2011). Horned melon is a dioecious plant with male flowers appearing several days before the female flowers (WilkinsEllert, 2004). The flowers forms in clusters of 1 to 4 and are small sized, bright yellow, funnel-shaped, axillary and opening to 5 lobes. The pistillate enlarges to form the fruit which grows above a prickly green ovary (Usman et al., 2015). The fruit is ellipsoid-cylindrically shaped and is normally light green when immature and bright orange at ripening (Bester and Condy, 2013). The skin has obscure longitudinal stripes of small pale markings, with sharp spines at the top (Usman et al., 2015). Unripe fruit is dark-green in colour. Ripe fruit has jelly-like translucent, green flesh filled with whitish seeds and with a refreshingly fruity taste and texture similar to a passion fruit (Weng, 2010).

Horned melon has high economic and nutritional value which has not been fully exploited (Aliero and Gumi, 2012). The flesh and the seeds can be eaten raw after being sprinkled with sugar or salt to enhance the flavour (Lim, 2012). The high moisture proportion in the fruit provides a good source of water for animals and human in the arid and semi-arid areas 
(April et al., 2018). The fruits can be baked whole or sliced and dried for future use (Lim, 2012). The fruit can also be sliced and added to tropical fruit salads (Wilkins-Ellert, 2004). Immature fruits can also be relished like cucumber but the nutritional value is rated twice higher than that of cucumber (Lim, 2012). Young leaves can be boiled and eaten like spinach. The ripe fruit can also be used for decoration purposes due to its interesting look (Cantwell, 2011). The pulp and the seeds can also be blended in a food processor for making refreshments such as yoghurts and ice creams (April et al., 2018). It can also be used as a substitute for vinegar in salad dressing (Mccormack, 2005).

Horned melon grows at an altitude range of 210 to $1800 \mathrm{~m}$ above sea level (Bester and Condy, 2013). It dominates both tropical and sub-tropical areas and cannot tolerate cold and mist conditions (Wilkins-Ellert, 2004). It prefers shallow or deep, well-drained, mostly alluvial sandy soil on river banks or flood plains, but has also been recorded from clay or loam soil and rocky slopes (Usman et al., 2015). Optimum growing temperature ranges between $20-30^{\circ} \mathrm{C}$ (Aliero and Gumi, 2012). However, its growth is not greatly affected by temperatures as high as $40^{\circ} \mathrm{C}$ although flowering seems to be affected by temperatures over $30^{\circ} \mathrm{C}$ and germination is greatly inhibited above $35^{\circ} \mathrm{C}$ (Aliero and Gumi, 2012). The plant can do well with as little as 350 to $550 \mathrm{~mm}$ of rainfall per season and dry air is beneficial during the harvest period (Cantwell, 2011). Semi-arid climate and warm season rainfall enhances the fruit ripening stage, enabling the fruit to develop full flavour (Aliero and Gumi, 2012).

Despite the numerous agronomic, nutritional, medicinal and economic advantages of horned melon, the crop remains less popular among farmers and consumers in most parts of the world (Wilkins-Eller, 2004) and thus its potential remains underutilized (Aliero and Gumi, 2012). The crop is also less studied by researchers and therefore its agronomic, nutritional and economic potential is not well documented. In Kenya, some horned melon accessions have been identified in various agro-ecological zones but their genetic and agronomic traits have not been studied. Consequently, no selection or genetic improvement has been conducted on this crop despite its high economic potential. It is expected that where this plant already exists in the wild or introduced in farmers' fields, a wealth of genetic diversity that can be utilized in its improvement would be found. This study therefore targeted to harness this genetic wealth as the basis for selection, genetic improvement and promotion of horned melon production in Kenya.

\section{Results}

\section{Assessment of the qualitative traits of horned melon}

The qualitative characters that were scored on the 19 horned melon accessions were growth habit, leaf blade, leaf shape, flower biology, corolla colour, fruit shape, predominant rind colour, design produced by secondary skin colour, skin stripe colour, presence of grooves on the fruit, flesh colour, seed shape and seed colour. Variations among accessions were only observed in fruit shape, predominant rind colour and seed shape. For the fruit shape, $74 \%$ of the accessions were elliptical in shape while $26 \%$ were cylindrically shaped. The cylindrical ones were from Maragua, Meru, Migori, Oyugis and Rongo. For the rind colour, $63.84 \%$ were light green while $36.16 \%$ were dark green. The dark green ones consisted of accessions from Kathwana, Maragua, Chuka, Kianjokoma, Migori, Kiambere and Oyugis. For the seed shape, $63.16 \%$ were elliptically shaped while $36.84 \%$ had pinonette shape. The pinonette shaped ones included accessions from Embu, Siakago, Chuka, Kathwana, Mitunguu, Machakos and Kwale.

There was no variation in all the other qualitative traits namely growth habit, leaf blade, leaf shape, flower biology, corolla colour, design produced by secondary skin colour, presence of grooves on the fruit, flesh colour and seed colour. The leaves had 3-palmately shallow lobed blade. Both male and female flowers were yellow in colour for all the accessions. The fruit had a mixture of both dotted and stripe skin design with green background and grooves present in the whole fruit. The flesh colour was green with white seeds. All the accessions were runners with a main vine that was highly branched.

\section{Assessment of the quantitative traits of horned melon}

Quantitative characters that were evaluated include vine length, number of branches on the main vine, fruit number, fruit weight, seed size and rind thickness. There were no significant differences ( $p>0.05)$ among accessions in main vine length, number of branches and fruit weight. However, significant differences $(p<0.05)$ among accessions were recorded in fruit number, seed size and rind thickness (Table 1). Rongo accession produced the highest number of fruits (17) per plant while Kangundo accession had the least (7) fruits. Maragua accession had the largest seed size $(4.10 \mathrm{~mm})$ while Kiambere accession had the smallest seed size $(3.17 \mathrm{~mm})$. Lastly, Machakos accession had the biggest rind thickness $(5.37 \mathrm{~mm})$ while Nyakoe accession had the smallest rind thickness $(3.01 \mathrm{~mm})$. All accessions had more than 100 seeds per fruit (data not analysed). Seasonal variations were not significant for all the quantitative variables (data not shown) indicating that different variables responded in a similar way to different production seasons.

\section{Assessment of the agronomic traits of horned melon}

Agronomic traits that were evaluated include percentage germination, days to emergence, days to male and female flowering and days to maturity. There were significant variations $(p<0.05)$ among accessions in all the agronomic characters as shown in Table 2. On seasonal average, Kathwana, Siakago, Kangundo and Embu accessions recorded $100 \%$ germination while Kehancha accession recorded the lowest germination of $54.33 \%$. Mitunguu accession took the shortest time to emerge ( 9 days) while Kathwana accession took the longest period of 11 days to emerge. Kehancha accession recorded the least days to male and female flowering (59 and 62 days respectively), while the Rongo accession took the most days (74 and 75 days respectively). In addition, Kehancha accession took the shortest period (102 days) to mature while Embu accession took the longest period 
Table 1. Variation in quantitative traits of horned melon accessions.

\begin{tabular}{|c|c|c|c|c|c|c|}
\hline Accessions & $\begin{array}{l}\text { Main Vine } \\
\text { Length }(\mathrm{cm})\end{array}$ & $\begin{array}{l}\text { Branch } \\
\text { Number }\end{array}$ & $\begin{array}{c}\text { Fruit } \\
\text { Number }\end{array}$ & $\begin{array}{l}\text { Fruit Weight } \\
(\mathrm{gm})\end{array}$ & $\begin{array}{l}\text { Seed Size } \\
(\mathrm{mm})\end{array}$ & $\begin{array}{l}\text { Rind thickness } \\
(\mathrm{mm})\end{array}$ \\
\hline Kathwana & 261.83 & 15.48 & $10.00^{\mathrm{abc}}$ & 226.33 & $4.00^{\mathrm{abcd}}$ & $4.24^{b}$ \\
\hline Meru & 250.58 & 13.75 & $13.17^{\mathrm{abc}}$ & 259.33 & $3.75^{\text {bcde }}$ & $4.28^{\mathrm{b}}$ \\
\hline Siakago & 249.42 & 16.00 & $14.88^{\mathrm{abc}}$ & 256.00 & $3.87^{\mathrm{abcd}}$ & $3.94^{\mathrm{bcd}}$ \\
\hline Maragua & 264.17 & 15.25 & $14.81^{\mathrm{abc}}$ & 246.00 & $4.10^{\mathrm{a}}$ & $3.61^{\text {cde }}$ \\
\hline Chuka & 258.67 & 14.67 & $11.03^{\mathrm{abc}}$ & 194.67 & $3.46^{\mathrm{ef}}$ & $3.12^{\mathrm{ef}}$ \\
\hline Kehancha & 253.33 & 16.58 & $10.97^{\mathrm{abc}}$ & 214.67 & $3.67^{\mathrm{de}}$ & $4.26^{b}$ \\
\hline Narok & 236.75 & 14.33 & $12.18^{\mathrm{abc}}$ & 207.00 & $3.73^{\text {cde }}$ & $3.46^{\text {def }}$ \\
\hline Kianjokoma & 249.17 & 13.83 & $10.79^{a b c}$ & 215.33 & $3.2^{f}$ & $3.16^{\mathrm{ef}}$ \\
\hline Kangundo & 263.25 & 16.00 & $7.41^{c}$ & 218.00 & $3.69^{\text {de }}$ & $4.12^{\mathrm{bc}}$ \\
\hline Kwale & 245.83 & 15.67 & $9.50^{\mathrm{abc}}$ & 227.67 & $4.00^{\mathrm{abcd}}$ & $3.19^{\mathrm{ef}}$ \\
\hline Rongo & 254.75 & 14.75 & $16.50^{\mathrm{a}}$ & 204.00 & $3.35^{f}$ & $3.72^{\text {cde }}$ \\
\hline Machakos & 267.92 & 15.58 & $12.85^{a b c}$ & 195.00 & $3.98^{\mathrm{abcd}}$ & $5.37^{\mathrm{a}}$ \\
\hline Migori & 240.83 & 14.83 & $13.38^{\mathrm{abc}}$ & 196.67 & $3.44^{\mathrm{ef}}$ & $3.12^{\mathrm{ef}}$ \\
\hline Mitunguu & 261.58 & 15.00 & $12.33^{\mathrm{abc}}$ & 214.33 & $4.07^{\mathrm{ab}}$ & $3.89^{\mathrm{bcd}}$ \\
\hline Wote & 277.08 & 16.21 & $16.07^{\mathrm{ab}}$ & 207.00 & $3.71^{\text {de }}$ & $3.66^{\text {cde }}$ \\
\hline Kiambere & 254.17 & 14.88 & $12.33^{\mathrm{abc}}$ & 214.67 & $3.17^{\dagger}$ & $3.20^{\mathrm{ef}}$ \\
\hline Embu & 265.25 & 15.00 & $10.96^{\mathrm{abc}}$ & 230.67 & $3.86^{\mathrm{abcd}}$ & $3.68^{\text {cde }}$ \\
\hline Nyakoe & 252.00 & 15.91 & $14.11^{\mathrm{abc}}$ & 226.00 & $4.05^{\mathrm{abc}}$ & $3.01^{f}$ \\
\hline Oyugis & 252.42 & 14.42 & $8.88^{b c}$ & 259.33 & $3.45^{\text {ef }}$ & $3.310^{\text {ef }}$ \\
\hline$P$ value & 0.949 (NS) & 0.987 (NS) & 0.005 & 0.470 (NS) & $<0.0001$ & $<0.0001$ \\
\hline SE & 9.823 & 1.021 & 1.477 & 14.410 & 0.076 & 0.128 \\
\hline
\end{tabular}

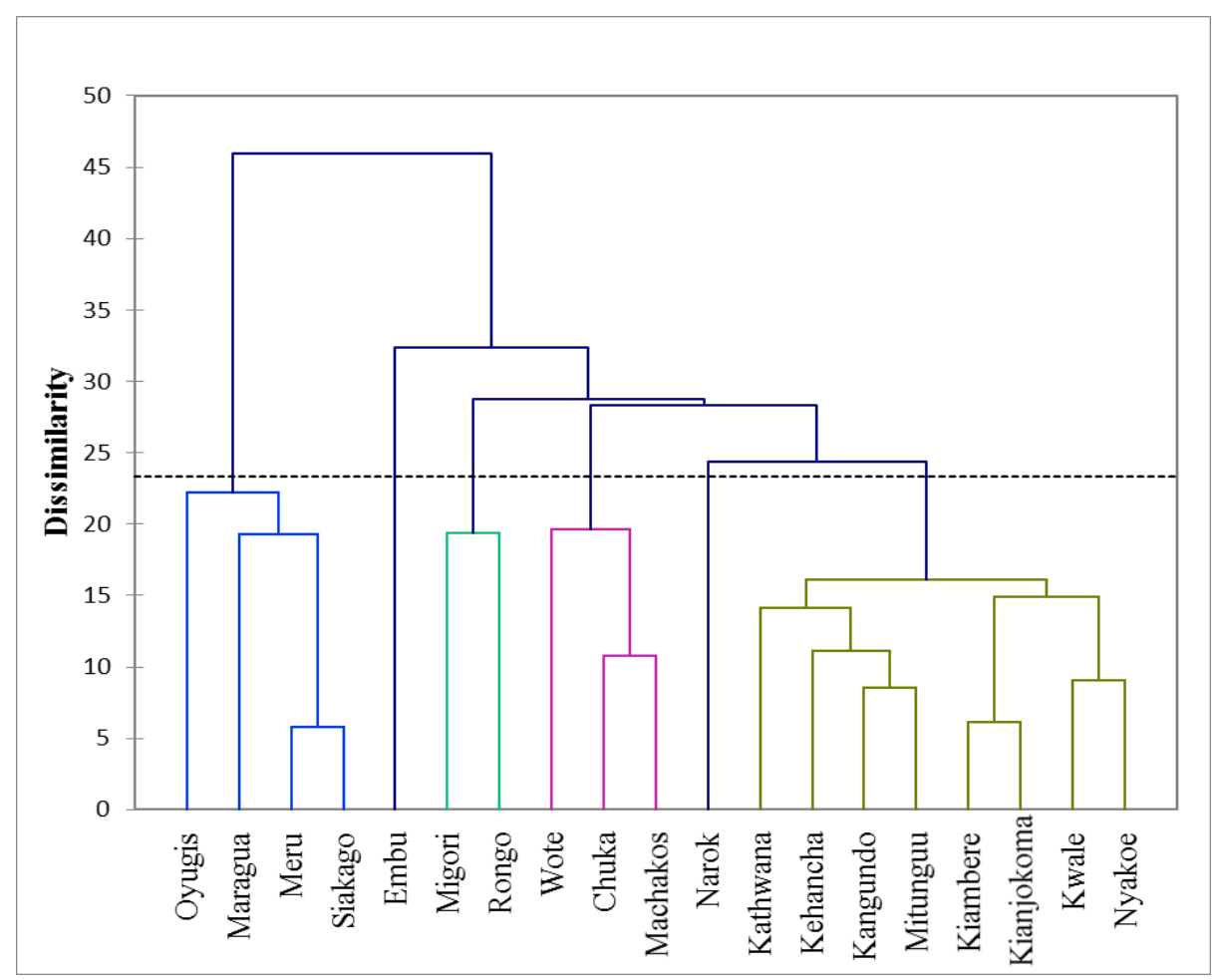

Fig 1. Cluster dendrogram depicting morphological diversity between horned melon accessions. 
Table 2. Variation in agronomic traits of horned melon accessions.

\begin{tabular}{|c|c|c|c|c|c|}
\hline Accessions & $\begin{array}{c}\text { Percent } \\
\text { Germination }\end{array}$ & $\begin{array}{c}\text { Days to } \\
\text { Emergence }\end{array}$ & $\begin{array}{l}\text { Days to Male } \\
\text { Flowering }\end{array}$ & $\begin{array}{l}\text { Days to Female } \\
\text { Flowering }\end{array}$ & Days to Maturity \\
\hline Kathwana & $100.00^{\mathrm{a}}$ & $11.00^{\mathrm{a}}$ & $63.67^{\text {bcde }}$ & $66.17^{\text {cdef }}$ & $103.00^{\text {de }}$ \\
\hline Meru & $90.17^{\mathrm{abc}}$ & $8.83^{\mathrm{e}}$ & $59.83^{\text {ef }}$ & $63.50^{\mathrm{fg}}$ & $105.00^{\mathrm{de}}$ \\
\hline Siakago & $100.00^{\mathrm{a}}$ & $9.17^{\text {de }}$ & $59.83^{\text {ef }}$ & $63.00^{\mathrm{ef}}$ & $104.83^{\mathrm{de}}$ \\
\hline Maragua & $91.67^{\mathrm{abc}}$ & $9.00^{\mathrm{e}}$ & $62.33^{\text {cdef }}$ & $65.33^{\mathrm{fg}}$ & $106.50^{\text {cde }}$ \\
\hline Chuka & $95.83^{\mathrm{ab}}$ & $9.67^{\text {cde }}$ & $61.17^{\text {def }}$ & $63.33^{\mathrm{fg}}$ & $107.17^{\text {cde }}$ \\
\hline Kehancha & $54.33^{d}$ & $9.67^{\text {cde }}$ & $58.50^{f}$ & $61.83^{\mathrm{g}}$ & $101.67^{\mathrm{e}}$ \\
\hline Narok & $72.33^{\mathrm{bcd}}$ & $9.67^{\text {cde }}$ & $59.17^{\dagger}$ & $62.33^{\mathrm{fg}}$ & $105.00^{\mathrm{de}}$ \\
\hline Kianjokoma & $91.67^{\mathrm{abc}}$ & $9.00^{\mathrm{e}}$ & $65.17^{b c d}$ & $67.83^{\text {bcde }}$ & $108.50^{\text {cd }}$ \\
\hline Kangundo & $100.00^{\mathrm{a}}$ & $8.83^{\mathrm{e}}$ & $59.50^{\mathrm{ef}}$ & $61.83^{\mathrm{g}}$ & $102.83^{\mathrm{de}}$ \\
\hline Kwale & $95.83^{\mathrm{ab}}$ & $9.67^{\text {cde }}$ & $63.50^{\text {bcde }}$ & $66.00^{\text {cdef }}$ & $104.17^{\mathrm{de}}$ \\
\hline Rongo & $66.67^{c d}$ & $10.00^{\mathrm{bcd}}$ & $73.50^{\mathrm{a}}$ & $74.67^{\mathrm{a}}$ & $114.83^{b}$ \\
\hline Machakos & $93.00^{\mathrm{ab}}$ & $10.33^{a b c}$ & $63.33^{\text {bcde }}$ & $65.67^{\text {cdefg }}$ & $106.00^{\text {cde }}$ \\
\hline Migori & $82.00^{\mathrm{abc}}$ & $10.83^{\mathrm{ab}}$ & $67.00^{b}$ & $69.00^{b c}$ & $120.50^{\mathrm{a}}$ \\
\hline Mitunguu & $97.17^{\mathrm{ab}}$ & $8.67^{\mathrm{e}}$ & $60.67^{\mathrm{ef}}$ & $63.33^{\mathrm{tg}}$ & $107.17^{\text {cde }}$ \\
\hline Wote & $82.00^{\mathrm{abc}}$ & $9.66^{\text {cde }}$ & $61.17^{\text {def }}$ & $64.33^{\text {efg }}$ & $105.50^{\text {de }}$ \\
\hline Kiambere & $93.00^{\mathrm{ab}}$ & $10.00^{\mathrm{bcd}}$ & $65.00^{b c d}$ & $68.00^{\mathrm{bcd}}$ & $111.50^{\mathrm{bc}}$ \\
\hline Embu & $100.00^{\mathrm{a}}$ & $10.16^{\mathrm{abc}}$ & $72.17^{\mathrm{a}}$ & $73.50^{\mathrm{a}}$ & $121.67^{\mathrm{a}}$ \\
\hline Nyakoe & $95.83^{\mathrm{ab}}$ & $10.33^{\mathrm{abc}}$ & $61.83^{\text {def }}$ & $64.83^{\text {defg }}$ & $106.67^{\text {cde }}$ \\
\hline Oyugis & $75.00^{\mathrm{abc}}$ & $9.50^{\text {cde }}$ & $66.00^{b c}$ & $69.50^{\mathrm{b}}$ & $122.16^{a}$ \\
\hline$P$ value & $<0.0001$ & $<0.0001$ & $<0.0001$ & $<0.0001$ & $<0.0001$ \\
\hline SE & 5.381 & 0.213 & 0.896 & 0.825 & 1.339 \\
\hline
\end{tabular}

Means followed by the same letter are not significantly different based on SNK test at $p \leq 0.05$. SE = Standard Error.

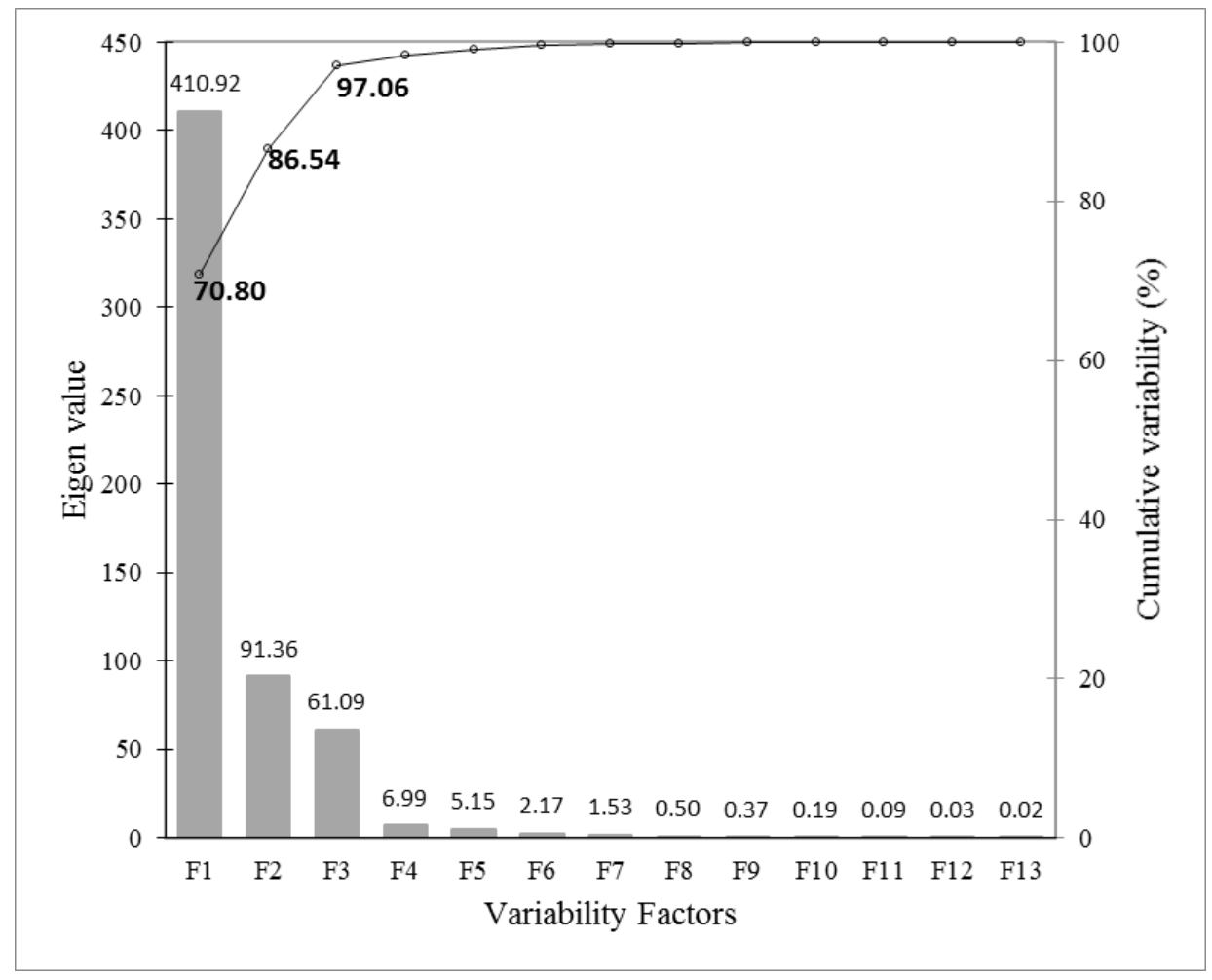

Fig 2. Scree plot of eigen values corresponding to variability factors. 
Table 3. Contribution of the variables to observed variation.

\begin{tabular}{llll}
\hline & \multicolumn{3}{l}{ Variability Factors } \\
\cline { 2 - 4 } Agro-morphological Variables & F1 & F2 & F3 \\
\hline Main Vine Length & 0.322 & 96.152 & 2.728 \\
Branch Number & 0.002 & 0.134 & 0.112 \\
Rind Colour & 0.000 & 0.051 & 0.260 \\
Fruit Shape & 0.022 & 0.043 & 0.247 \\
Seed Shape & 0.001 & 0.134 & 0.003 \\
Fruit Number & 0.011 & 0.058 & 0.099 \\
Days to Seed Emergence & 0.016 & 0.008 & 0.085 \\
Days to Male Flowering & 0.054 & 0.162 & 22.369 \\
Days to Female Flowering & 0.004 & 0.180 & 18.092 \\
Days to Maturity & 0.023 & 2.650 & 55.946 \\
Fruit Weight & 99.544 & 0.334 & 0.013 \\
Seed Size & 0.001 & 0.013 & 0.016 \\
Rind Thickness & 0.000 & 0.081 & 0.030 \\
\hline Eigenvalue & 410.922 & 91.356 & 61.095 \\
Variability (\%) & 70.797 & 15.740 & 10.526 \\
Cumulative \% & 70.797 & 86.537 & 97.063 \\
\hline
\end{tabular}

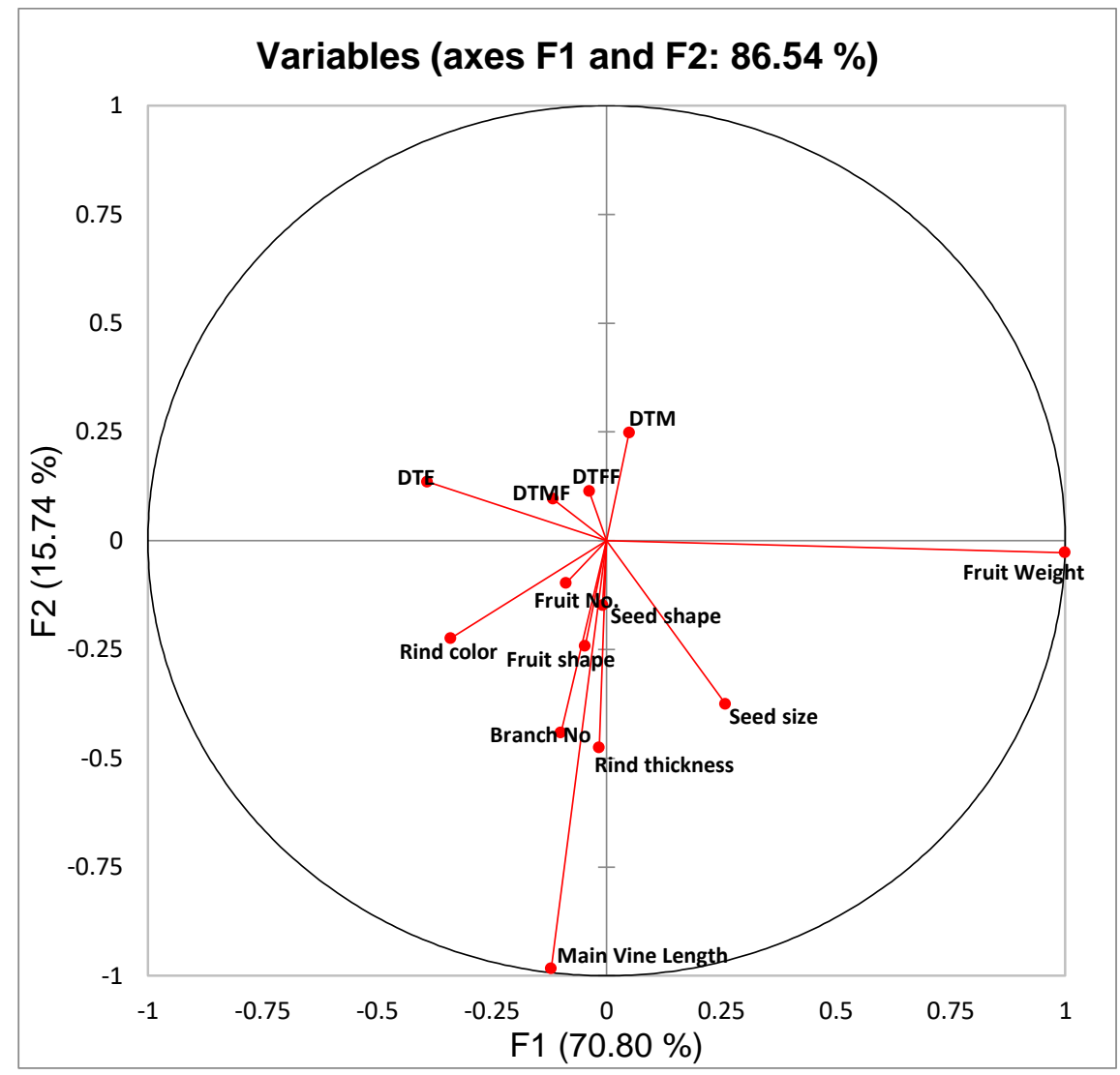

Fig 3. Pictorial illustration of the principal component analysis. 
Table 4. List of horned melon accessions evaluated in the study.

\begin{tabular}{|c|c|c|c|c|c|}
\hline S/No. & $\begin{array}{l}\text { Accession } \\
\text { Code }\end{array}$ & County & $\begin{array}{l}\text { Place of } \\
\text { Collection }\end{array}$ & AEZ & GPS Coordinates \\
\hline 1. & ACC1 & Tharaka-Nithi & Kathwana & UM & $0.327201 S, 37.866059 \mathrm{E}$ \\
\hline 2. & ACC2 & Meru & Meru & UH & $0.051541 \mathrm{~N}, 37.645855 \mathrm{E}$ \\
\hline 3. & ACC3 & Embu & Siakago & LM & $0.577330 \mathrm{~S}, 37.640544 \mathrm{E}$ \\
\hline 4. & ACC4 & Murang'a & Maragua & UM & $0.799959 S, 37.133016 \mathrm{E}$ \\
\hline 5. & ACC5 & Tharaka-Nithi & Chuka & UH & $0.331004 S, 37.647958 \mathrm{E}$ \\
\hline 6. & ACC6 & Migori & Kehancha & UM & 1.193604S, 34.615860E \\
\hline 7. & $\mathrm{ACC} 7$ & Narok & Narok & $\mathrm{LH}$ & 1.085049S, 35.877356E \\
\hline 8. & ACC8 & Embu & Kianjokoma & UM & $0.395741 S, 37.503827 \mathrm{E}$ \\
\hline 9. & ACC9 & Machakos & Kangundo & LM & $1.299215 \mathrm{~S}, 37.350726 \mathrm{E}$ \\
\hline 10. & ACC10 & Kwale & Kwale & LH & 4.181473S, 39.460144E \\
\hline 11. & ACC11 & Migori & Rongo & LM & $0.746204 S, 34.595284 \mathrm{E}$ \\
\hline 12. & ACC12 & Machakos & Machakos & LM & $1.528227 \mathrm{~S}, 37.263005 \mathrm{E}$ \\
\hline 13. & ACC13 & Migori & Migori & UM & $1.070804 \mathrm{~S}, 34.472522 \mathrm{E}$ \\
\hline 14. & ACC14 & Meru & Mitunguu & UH & $0.108490 \mathrm{~S}, 37.784815 \mathrm{E}$ \\
\hline 15. & ACC15 & Makueni & Wote & LM & 1.788249S, 37.633152E \\
\hline 16. & ACC16 & Embu & Kiambere & LM & $0.684613 S, 37.792102 E$ \\
\hline 17. & ACC17 & Embu & Embu & UM & $0.487726 \mathrm{~S}, 37.458003 \mathrm{E}$ \\
\hline 18. & ACC18 & Kisii & Nyakoe & LM & $0.627900 S, 34.762945 \mathrm{E}$ \\
\hline 19. & ACC19 & Homabay & Oyugis & LM & $0.507982 S, 34.737482 \mathrm{E}$ \\
\hline
\end{tabular}

(122 days) to mature. Seasonal variations were significant for days to emergence $(p<0.001)$, days to male flowering $(p<0.0001)$ and days to female flowering $(p<0.0001)$. These variables therefore responded differently to different seasons.

\section{Correlation analysis}

Relationship between the quantitative and agronomic traits was assessed using a Pearson's correlation matrix. There was positive significant $(p<0.05)$ correlation between days to male flowering and days to female flowering $(r=0.992)$, days to male flowering and days to maturity $(r=0.785)$, as well as days to female flowering and days to maturity $(r=0.809)$. All the other variable combinations (data not presented) had no significant relationship.

\section{Cluster analysis}

A cluster dendrogram constructed using the quantitative and qualitative traits was used to estimate the genetic diversity among the nineteen horned melon accessions. Results of the cluster analysis using the combined season morphological data are illustrated in Figure 1 . The accessions separated into seven (7) clusters with a between classes diversity of $79.20 \%$ and within classes diversity of $\mathbf{2 0 . 8 0 \%}$. Accessions from Kathwana, Kehancha, Kangundo, Mitunguu, Kiambere, Kianjokoma, Kwale and Nyakoe clustered together indicating higher level of similarity between them. The second largest cluster had four accessions from Oyugis, Maragua, Meru and Siakago while Machakos, Chuka and Wote accessions clustered together. Migori and Rongo accessions clustered together in their own cluster while accessions from Embu and Narok each separated into their own singleton cluster.

\section{Principal component analysis}

Principal component analysis (PCA) was used to analyse the contribution of the variables to the total variation observed between the nineteen horned melon accessions. The results for the 13 variables used indicated that the first three variability factors (F1, F2 and F3) explained $97.06 \%$ of the total variation with F1 explaining variability of $70.78 \%$, F2 with $15.74 \%$ and $\mathrm{F} 3$ with $10.53 \%$ of the total variation. All the other ten (10) variablity factors explained only $2.94 \%$ of the total variation (Figure 2 ). The variables contributed differently to the observed variation with fruit weight, main vine length and days to maturity contributing the highest to F1 (99.54\%), F2 (96.15\%) and F3 (55.95\%) respectively (Table 3; Figure 3). Days to male and female flowering also contributed significantly to F3 with $22.37 \%$ and $18.09 \%$ contribution respectively. The rest of the variables contributed minimally to the three principal factors (Table 3; Figure 3).

\section{Discussion}

\section{Variation in qualitative traits of horned melon}

Significant genetic diversity was observed between the horned melon accessions based on morphological and agronomic variation. However, most of the qualitative traits were similar in all accessions except fruit shape, seed shape and predominant rind colour. Similar observation was made by Bisognin (2002) and Gichimu et al. (2009a) who reported that cucurbits are similar in above ground development but have high genetic diversity in fruit characteristics such as fruit shape, flesh colour, seed shape and seed colour. Most of the accessions (74\%) had elliptically shaped fruits while the rest (26\%) had cylindrically shaped fruits. The seeds for most of the 
accessions (63.16\%) were also elliptically shaped while rest (36.84\%) had pinonette shaped seeds. This observation concurred with earlier report by Bester and Condy (2013) that the fruits of $C$. metuliferus were ellipsoid-cylindrically shaped. The rind colour varied from light green to dark green with majority of the accessions being dark green. However, the fruit colour in all accessions changed to bright orange at ripening. Similar observation was made by Dembitsky et al. (2011) and Usman et al. (2015).

\section{Variation in quantitative traits of horned melon}

Quantitative characters that were evaluated include main vine length, number of branches on the main vine, fruit number, fruit weight, rind thickness and seed number. The former four are considered to be yield components while the latter two are quality components (Gichimu et al., 2009b). Among the yield components, only fruit number recorded significant differences among accessions; ranging from an average of 17 fruits produced by the Rongo accession to 7 fruits produced by Kangundo accession. Unfortunately, the prolific nature of the Rongo accession may have compromised the fruit weight which averaged $204 \mathrm{~g}$, a far cry from $259 \mathrm{~g}$ recorded by Oyugis and Meru accessions. However, this could be possibly improved by enhancing the soil fertility since high yielding accessions are expected to have a relatively higher demand of essential nutrients. Apparently, C. metuliferus is highly variable in terms of fruit yield as different studies have reported divergent data on fruit number and weight. April et al. (2018) reported that each vine is capable of producing up to 100 fruits. In a study evaluating 26 C. metuliferus plant introductions in Missouri, United States, Marsh (1993) obtained fruit numbers ranging from 14 to 101 fruits per plant but with relatively lower fruit weights ranging from 12 to 31 grams.

For successful yield selection, all the yield components should be considered. Although there were no significant variations among accessions in vine length and branch number, these variables are expected to have a significant influence on yield as reported by April et al. (2018). Similar observation was also made by Deepa et al. (2018) in cucumber who also reported that the yields were strongly correlated to branch number and vine length. In the contrary and against expectations, this study observed no significant correlation between the yield components. This observation was attributed to the fact that some accessions managed to produce many fruits despite not being well endowed with long vines and many branches. Similarly, some accessions with long vines and many branches produced relatively fewer fruits. This was an indication that there is high breeding potential to improve the yields of horned melon through selective hybridization of accessions possessing desirable yield components. For example, the potential of the Rongo accession can be further expanded by increasing the vine length and branch number through hybridization with the Wote accession which was found to combine long vine length with high branch number and fruit number.

Significant differences among accessions were also recorded in seed size and rind thickness. This evaluation was important because both the seeds and the rind of horned melon are edible. The seed size ranged from $3.17 \mathrm{~mm}$ recorded in
Kiambere accession to $4.10 \mathrm{~mm}$ recorded in Maragua accession. This observation was divergent from what was reported by Wilkins-Ellert (2004) that the seeds of $C$. metuliferus are 5-8 $\mathrm{mm}$ long. All accessions had more than 100 seeds per fruit. Rind thickness also varied from $5.37 \mathrm{~mm}$ recorded in the Machakos accession to $3.01 \mathrm{~mm}$ recorded in the Nyakoe accession. There was no available data in literature comparing the rind thickness among different accessions of horned melon. There were no significant seasonal variations between accessions for all the quantitative variables indicating that the accessions were genetically stable and may not be significantly affected by genotype by environment interactions. This is a positive agronomic trait that would ensure constant productivity of the horned melon across variable weather conditions.

\section{Contribution of variables to the observed diversity}

Although there were no significant variations among accessions in fruit weight and main vine length, the PCA indicated that the two had the highest contribution to the total variation observed between the nineteen accessions studied. This was an indication that there was a high potential of agronomic selection among the accessions based on these variables. The average length of the main vine ranged from $236.75 \mathrm{~cm}$ recorded in the Narok accession to $277.08 \mathrm{~cm}$ recorded in Wote accession. This big gap between the shortest and the longest vine is an indication of the improvement potential among the accessions studied. However, the vine length obtained in this study fell short of the $5 \mathrm{~m}$ length reported by April et al. (2018). Similarly, high improvement potential was observed in fruit weight whose variation among accessions varied from 195.0 grams produced by Machakos accession to 259.33 grams produced by Meru and Oyugis accessions. This was slightly high than the average of 200 grams reported by Wilkins-Ellert (2004) in Israel. However, unlike vine length whose potential is a combined effect of the genetics and agronomic nourishment, fruit weight may be affected by fruit number unless the plant is adequately and timely supplied with all essential growth resources.

\section{Variation in agronomic traits of horned melon}

Unlike the growth variables, other agronomic variables namely, percent germination, days to seed emergence, days to male and female flowering and days to maturity recorded highly significant variations between accessions. This was expected as all these variables are liable to be affected by the weather especially the temperature and the accessions were all collected from different geographical locations where they may have adopted to different weather patterns. Variation in flowering time on $C$. metuliferus was also reported by Weng (2010). Most of the accessions recorded high viability of between 80 and $100 \%$ except five accessions whose germination percentage was lower than $80 \%$. These were accessions from Kehancha, Rongo, Narok and Oyugis. This observation was consistent over the two seasons indicating that its cause could be genetically linked and acquired from the original habitat. Aliero and Gumi (2012) also observed high germination percentage averaging $96.66 \%$ with untreated seeds of horned melon. Significant positive correlation that 
was observed between days to male and female flowering and days to maturity was an indication that these variables are genetically linked thus selection for one would automatically improve the others. Principal component analysis also showed that these three variables contributed significantly to the total variation observed between the accessions and therefore they can be easy targets for selective improvement of the accessions.

\section{Cluster analysis}

A cluster dendrogram developed using the qualitative and quantitative traits as well as the agronomic variables indicated that there was significant genetic variation between the accessions studied. The accessions separated into seven (7) clusters with a between classes diversity of $79.20 \%$ and within classes diversity of $20.80 \%$. This was a considerable high level of genetic diversity for accessions of the same species and further underscores the enormous selection potential that exists within horned melon accessions. There are scanty reports on the genetic characterization of $C$. metuliferus accessions in Kenya. A related study conducted by Gichimu et al. (2009a) on watermelon accessions obtained relatively lower genetic diversity of $42-54 \%$ between classes and $8-27 \%$ within classes. Other previous studies conducted by Henan et al. (2013) on muskmelon in Tunisia and Solmaz et al. (2010) on melon genotypes collected from Eastern and Central Anatolia region of Turkey also reported high morphological variation between cucurbits. In another genetic diversity study conducted by Weng (2010) among C. metuliferus accessions using cucumber microsatellites, unexpectedly low genetic diversity was observed between 36 accessions. The 42 microsatellite markers only managed to separate the accessions into six supported groups detecting on average 3.3 alleles across the $36 \mathrm{C}$. metuliferus accessions and 12 of them were monomorphic. The effect of the region of origin of the accessions was evident as most accessions clustered according to the proximity of their places of origin (where they were collected). For example, the Rongo and Migori accessions that were both from Migori County clustered together. Similarly, the Wote, Machakos and Chuka accessions all of which were from the Eastern Kenya region clustered together as it was the case with Kathwana, Kangundo, Mitunguu, Kiambere and Kianjokoma accessions which were also from Eastern Kenya region. Similar observation was reported by Weng (2010) when studying the genetic diversity of $C$. metuliferus populations using cucumber microsatellites where he noted that accessions that were collected from nearby locations were clustered in the same group. However, some accessions that were collected from distinctively diverse geographical regions clustered together which was an indication of high agronomic potential of horned melon over a wide range of environmental conditions. This observation was further supported by the fact that all the nineteen accessions with diverse geographical origin managed to produce appreciably in a common location. Therefore, there is wide agronomic range of horned melon in Kenya and this supports the previous report by Wilkins-Ellert (2004) that horned melon occurs at altitudes from near sea level to $1800 \mathrm{~m}$ and tolerate a wide range of soil types throughout their natural distribution area.

\section{Materials and Methods}

\section{Description of the study site}

The study was carried out at University of Embu research farm. The University is located along Nairobi - Meru highway in Manyatta sub-county in Embu County, Kenya. The research site lies on latitude $0^{\circ} 31^{\prime} 52.03^{\prime \prime} \mathrm{N}$ and longitude $37^{\circ} 27^{\prime} 2.20^{\prime \prime}$ $\mathrm{E}$ at an elevation of $1480 \mathrm{~m}$ above sea level (Jaetzold et al., 2006). The area receives mean annual rainfall of about 1200 $\mathrm{mm}$ received in two distinct rainy seasons; the long rains (midMarch to August) averaging $650 \mathrm{~mm}$ and the short rains (midOctober to February) averaging $450 \mathrm{~mm}$ (Muthee et al., 2019). The mean annual temperature is $19.5^{\circ} \mathrm{C}$, a mean maximum and minimum of $25^{\circ} \mathrm{C}$ and $14.1^{\circ} \mathrm{C}$, respectively. The mean annual potential evaporation is $1422 \mathrm{~mm}$ while mean annual evapotranspiration is $950 \mathrm{~mm}$ (Jaetzold et al., 2006). The soils are mainly humic nitisols derived from basic volcanic rocks. They are deep, highly weathered with friable clay texture and moderate to high inherent fertility (FAO, 2011). Most farmers rely on production of crops like maize and horticultural crops such as melons.

\section{Plant materials and seed preparation}

Nineteen accessions of mature horned melon fruits were collected from the wild and farmers' fields from selected counties in Kenya where the crop is grown. These counties include Meru, Embu, Makueni, Kisii, Homabay, Muranga, Narok, Machakos, Tharaka Nithi, Kwale and Migori. The materials were collected from different agro-ecological zones (AEZ) as shown in Table 4. The ripened fruits were then transported in well labelled bags to the University of Embu for extraction of seeds that were used in the establishment of the crop. The fruits were cut open with a sharp knife and the pulp carefully scooped out using clean spatula. The obtained seeds were separately fermented to remove the jelly-like substance and to soften the seed coat (Mccormack, 2005). This was done in plastic containers using pure water for three days after which the seeds were sun-dried and then winnowed to separate the seeds from chaff (Aliero and Gumi, 2012).

\section{Experimental design and layout}

The experiment was laid out in a Randomized Complete Block Design with three replications. The nineteen different accessions were used as treatments and were allocated experimental plots measuring $3 \mathrm{~m}$ by $3 \mathrm{~m}$. A $1 \mathrm{~m}$ wide alley was provided between plots to avoid any interference with the plants during data collection and crop husbandry. Three seeds were planted per hole at a spacing of $1 \mathrm{~m}$ by $1 \mathrm{~m}$ and later thinned to one seedling a week after germination. Well decomposed farm yard manure and TSP fertilizer were applied in the planting holes before sowing at the recommended rates of $30 \mathrm{t} / \mathrm{ha}$ and $200 \mathrm{Kg} / \mathrm{ha}$, respectively. Each plot comprised of five plants and data were collected from four tagged plants. Two rows of the Embu accession were used as guard rows around the experimental field. Other agronomic practices including irrigation, pests and weeds control were done uniformly in all the plots whenever necessary. The study was 
carried out in two seasons from October 2018 to January 2019 and from March to July 2019.

\section{Data collection}

A descriptor list with 21 morphological characters was adopted from International Plant Genetic Resources Institute (IPGRI) (Díez et al., 2005; Jarret and Griffin, 2007) and was modified to suit the characterization of horned melon. Data were collected on qualitative and quantitative morphological characters of horned melon including leaf shape, growth habit, predominant rind colour, flesh colour, fruit shape, seed shape, seed size, seed colour, rind thickness, number of seeds per fruit, main vine length, number of branches per plant, fruit number per plant and average fruit weight. Data were also collected on other agronomic characters such as percent germination, days to seedling emergence, days to female and male flowering and days to maturity. Qualitative traits were scored as described in the descriptor while quantitative data were taken as an average of the measurements made on four tagged plants per replicate. A digital vanier calliper was used to measure the rind thickness of the fruits while average fruit weight was measured using a digital balance model PLT 750DXXL with a readability of 50 grams.

\section{Statistical analysis}

Quantitative and agronomic data for the two seasons was combined and subjected to a two-way analysis of variance (ANOVA) at 5\% level of significance using XLSTAT Version 2019 to test for the significant differences between accessions, seasons and interactions between accessions and seasons. Separation of means was done using Students Newman's Keuls (SNK) at $95 \%$ level of confidence. Pearson correlation coefficients were carried out between growth and yield components. Qualitative and quantitative data were then organized into a matrix and subjected to cluster analysis. Estimates of similarity among the genotypes were calculated using dissimilarity units and expressed as Euclidean genetic distance (Kaçar et al., 2012). Dissimilarity indices were used to generate a dendrogram using the unweighted pair group method with arithmetic average (UPGMA). Truncation was performed based on the classes' diversity. Principal component analysis (PCA) was also carried out using the quantitative and agronomic variables to analyse their contribution to the total morphological diversity.

\section{Conclusion}

This study established that there exists considerably high genetic variation within horned melon which can be exploited by plant breeders for genetic improvement of this high value crop whose potential is yet to be fully utilized. The study further established that there is great breeding potential to improve the yields of horned melon through selective hybridization of accessions possessing desirable yield components. In addition, the study findings indicated that horned melon has a high agronomic potential over a wide range of environmental conditions as accessions from diverse geographical regions recorded appreciable yields in a common location. Therefore, plant breeders should embark on improving the agronomic and quality attributes of this crop through targeted selection and hybridization. The best performing cultivars should then be promoted among farmers in all agro-ecological zones in Kenya.

\section{Acknowledgements}

The authors are thankful to the National Genebank of Kenya, in Muguga for provision of some of the seeds that were used in this study. University of Embu is acknowledged for the provision of the study site.

\section{References}

Aliero AA, Gumi AM (2012) Studies on the germination, chemical composition and antimicrobial properties of Cucumis metuliferus. Ann Biol Res. 3 (8):4059-4064.

April M, Usman JG, Sodipo OA, Kwaghe AV, Wampana B, John $N$ (2018) Effects of crude methanol extract of the fruit of Cucumis metuliferus (Cucurbitaceae) on some haematological parameters in cockerels. J Phyto. 7(2): 106110.

Bester SP, Condy G (2013) Cucumis metuliferus E.Mey. Ex Naudin. Flowering Plants of Africa. 63: 56-64.

Bisognin DA (2002) Origin and evolution of cultivated cucurbits. Cienc Rural. 32 (5): 715-723

Cantwell M (2011) Storage of kiwano (horned melon) fruits. Department of Plant Sciences, University of California, Davis CA. 20, p 3-7.

Deepa SK, Hadimani HP, Hanchinamani CN, Shet R, Koulgi S, Ashok (2018) Studies on character association in cucumber (Cucumis sativus L.). Int J Curr Microbiol Appl Sci. 7(11): 1977-1982.

Dembitsky VM, Poovarodom S, Leontowicz H, Leontowicz M, Vearasilp S, Trakhtenberg S, Gorinstein S (2011) The multiple nutrition properties of some exotic fruits: Biological activity and active metabolites. Food Res Int. 44(7): 1671-1701.

Deguine JP, Atiama-Nurbel T, Aubertot JN, Augusseau $X$, Atiama M, Jacquot M, Reynaud B (2015) Agro-ecological management of cucurbit-infesting fruit fly: a review. Agron Sustain Dev. 35(3): 937-965.

Díez MJ, Dooijeweert W, Maggioni L, Lipman E (2005) Minimum descriptor lists for cucurbit; cucumber, melon and watermelon. Report of a working group on cucurbits presented at the first meeting, Plovdiv, Bulgaria, 1-2 September 2005.

FAO (2011) The state of the world's land and water resources for food and agriculture (SOLAW). Managing systems at risk. Food and Agriculture Organization of the United Nations, Rome.

Gichimu BM, Owuor BO, Mwai, GN, Dida MM (2009b) Morphological characterization of some wild and cultivated watermelon (Citrullus sp.) accessions in Kenya. Res J Agric Biol Sci. 4(2): 10-18.

Gichimu BM, Owuor BO, Dida MM (2009a) Comparing the yield components of three most popular commercial watermelon cultivars in Kenya with one newly introduced cultivar and one landrace. J Plant Breed Crop Sci. 1(4): 65-71.

Henan I, Tlili I, llahy R, Rhim T, Jebari H (2013) Evaluation of qualitative parameters and physicochemical properties of local varieties of muskmelon (Cucumis melo L.) grown in 
Tunisia. Global Science Books 7: 17-21. Horticultural Crops Directorate (HCD) (2016) Horticulture Validated Report 2015-2016, Agriculture and Food Authority (AFA), Nairobi, Kenya, $\mathrm{p} 60$.

Jaetzold R, Schmidt H, Hornetz B, Shisanya C (2006) Farm Management Handbook of Kenya, 2nd edition, Volume II: Natural conditions and farm management information. Part C: East Kenya: Ministry of Agriculture/GTZ. Nairobi, Kenya.

Jarret B, Griffin GA (2007) Watermelon descriptor site(s): S9. Contains characteristic data on Citrullus (watermelon) accessions. Bioversity International - FAO, Rome, Italy.

Kaçar YA, Simsek O, Solmaz I, Sari N, Mendi, YY (2012) Genetic diversity among melon accessions (Cucumis melo) from Turkey based on SSR markers. Genet Mol Res. 11(4): 46224631.

Muthee Al, Gichimu BM, Nthakanio PN (2019) Analysis of banana production practices and constraints in Embu County, Kenya. Asian J Agric Rural Dev. 9(1): 123-132.

Lim TK (2012) Edible Medicinal and Non-Medicinal Plants. Volume 2, Fruits. Springer, New York.

Marsh DB (1993) Evaluation of Cucumis metuliferus as a specialty crop for Missouri. In: J. Janick and J.E. Simon (eds.) New crops, Wiley, New York, p. 558-559.

Mccormack JH (2005) Cucurbit seed production - An organic seed production manual for seed growers in the Mid-Atlantic and Southern US, Charlottesville, VA 22911, p 1-36.
Solmaz I, Sari N, Yalcin MY, Aka Kacar Y, Kasapoglu S, Gursoy I, Suyum K, Killi O, Serce S, Yildirim E (2010) The characterization of some melon genotypes collected from Eastern and Central Anatolia region of Turkey. Acta Hortic. 871: 187-196.

Tshilidzi M, Sibanda S, Yamdjeu AW, Moalosi K, Gwelo FA (2016) Achieving food security and nutrition. In: Progress towards agricultural transformation in Africa. Africa Agriculture Status Report. 2016, p 288.

Usman JG, Sodipo OA, Kwaghe AV, Sandabe UK (2015) Uses of Cucumis metuliferus: A Review. Cancer Biol. 5(1):24-34.

Wannang NN (2011) Aqueous fruit extract of Cucumis metuliferus E Mey. Ex Naud (Cucurbitaceae) alters behavioural cctivities in chicks. Production Agriculture and Technology. 7 (1): 84-89.

Wang YH, Joobeur T, Dean, RA, Staub JE (2007) Cucurbits genome mapping and molecular breeding in plants. Nat Genet. 41:1275-1281.

Weng Y (2010) Genetic diversity among Cucumis metuliferus populations revealed by cucumber microsatellites. HortScience. 45(2):214-219.

Wilkins-Ellert MH, (2004) Cucumis metuliferus E.Mey. Ex Naudin. Record from PROTA4U. In: Grubben GJH, Denton OA (Eds). PROTA (Plant Resources of Tropical Africa / Resources végétales de l'Afrique tropicale), Wageningen, Netherlands. 